\title{
Effect of season, genotype and lactation on milk yield and composition of local and crossbred dairy cows reared under different feed base region \\ M. A. Baset, ${ }^{1}$ K. S. Huque, ${ }^{2}$ N. R. Sarker, ${ }^{2}$ M. M. Hossain,${ }^{3}$ and M. N. Islam ${ }^{4}$ Sylhet Agricultural University, Sylhet 3100, Bangladesh
}

\begin{abstract}
A total of 160 cows, 10 cows in each of native (local cow) and crossbred (local $\times$ Holstein Friesian) origins differing in lactation were used in $2 \times 2 \times 2 \times 2$ factorial experiment using Randomized Block Design (RBD) to evaluate milk yield and composition of cows considering regions (good \& poor feed base region), seasons (dry: Nov.-Feb. 2009 \& wet: Jun.-Oct. 2009), genotypes and lactation. A "good and/or poor feed base" region was classified based on the availability of quantity and quality roughages throughout the year. The study revealed that the daily milk yield and 4\% FCM of cows under good feed base condition were 6.76 and $6.49 \mathrm{~kg}$, respectively and under poor feed base condition were 3.67 and $3.31 \mathrm{~kg}$, respectively. Feed base region did not affect on milk fat and it was observed that the milk protein, lactose, solids-not-fat (SNF), minerals and total solids under good feed base condition were $37.9,54.9,100.9,6.3$ and $140.6 \mathrm{~g} / \mathrm{kg}$, respectively, whereas, under poor feed base condition the values were $36.3,52.9,98.0,6.1$ and $135.2 \mathrm{~g} / \mathrm{kg}$, respectively. Season did not affect milk yield and composition except minerals $(6.5 \mathrm{~g} / \mathrm{kg}$ vs. $5.9 \mathrm{~g} / \mathrm{kg})$. Genotypes significantly $(\mathrm{p} \leq 0.01)$ influenced daily milk yield, the milk protein and minerals. Lactation did not affect milk yield and the milk protein, but influenced the fat, lactose, SNF, minerals and total solids. The interaction of feed base regions and seasons significantly $(p \leq 0.01)$ influenced milk yield and the milk fat and SNF. The milk protein and lactose was influenced by the interaction of feed bases region, seasons and lactation. Milk yield negatively correlated with fat per cent. The percentage of fat significantly $(\mathrm{p} \leq 0.01)$ correlated with protein, lactose, SNF, and minerals $\%$. The percentage protein correlated with lactose, SNF and minerals. Lactose $\%$ significantly $(p \leq 0.01)$ correlated with SNF\%. It may be concluded that milk yield and composition depends on feed base region, genotype and lactation of cows. Season did not influence milk yield and the composition. Milk yield negatively correlated with the percentage of fat, protein, lactose, SNF and milk composition strongly correlated with each other.
\end{abstract}

(Key words: Milk yield, milk composition, season, genotype, lactation)

\section{Introduction}

Bangladesh has 24 million cattle, out of which 6 million are dairy cattle (DLS, 2008), consisting of local (31.45\%) and crossbreds (68.55\%) reported by Huque et al. (2002). The

\footnotetext{
${ }^{1}$ Corresponding author: Department of Livestock Production and Management, Sylhet Agricultural University, Sylhet 3100, Bangladesh, mabaset1968@gmail.com

${ }^{2}$ Animal Production Research Division, Bangladesh Livestock Research Institute, Dhaka 1341, Bangladesh

${ }^{3}$ Department of Animal Science, Bangladesh Agricultural University, Mymensingh 2202, Bangladesh

${ }^{4}$ Department of Dairy Science, Bangladesh Agricultural University, Mymensingh 2202, Bangladesh
} 
majority of the cattle are reared by smallholder dairy producers. The numbers of dairy farms are estimated at about 1.4 million with an average herd size of 1-3 cows (Hemme, 2008). Dairy is a part of the mixed farming systems in Bangladesh (Saadullah, 2001) and a predominant source of income, nutrition and jobs (Miyan, 1996; Haque, 2009). Dairying is also considered a strong tool to develop a village micro economy of Bangladesh (Shamsuddin et al.2007) in order to improve rural livelihoods and to alleviate rural poverty.

Milk production growth has increased from 4.1\% to 7.4\% per annum in 2000-2005 and 20052008, respectively (Hemme, 2008). Even with this faster growth the per capita milk availability in 2008 was only $19 \mathrm{~kg}$ (Hussain et al. 2008), which was far below the requirements (92 kg/person/year) as indicated by the World Health Organization (WHO, 2002). The average consumption of milk is at a rate of $4 \%$ per year (Hemme, 2008). This means that in future the dairy industry of Bangladesh will be 'demand-' or 'market-driven' which corresponds to the doubling of demand for milk and milk products in 2020 in all developing countries including Bangladesh (Delgado et al.1999, Ndambi et al.2007).

Milk, one of the physiological products of cows, varies in composition depending on plan of nutrition of cows. Relation between the composition of milk and the diets fed to cows may produce some options to develop feeding guides for milking cows. The actual amount of milk and composition produced during the lactation period is affected by feeds (Mackle et al.1999), seasons (Hang et al., 1982 and Auldist et al.1998), stage of lactation (Sharma et al.1985; Auldist et al.1998), etc.

The lack of information is available to understand the effect of nutritional and non-nutritional factors on milk yield and composition of local and cross-bred cows in Bangladesh. Therefore, in the light of above discussed features, the present investigation was intended to assess the effect of season, genotype and lactation on milk yield and composition of local and crossbred dairy cows reared under different feed base management.

\section{Materials and Methods}

\section{Design of experiment}

A total of 160 cows, 10 cows in each of native (local cow) and crossbred (local $\times$ Holstein Friesian) origins differing in lactation were used in $2 \times 2 \times 2 \times 2$ factorial experiment using Randomized Block Design (RBD) to evaluate milk yield and composition of cows considering regions (good \& poor feed base region), seasons (dry: Nov.-Feb. 2009 \& wet: Jun.-Oct. 2009), genotypes (local cow: $247 \mathrm{~kg}$ and crossbred cow: $318 \mathrm{~kg}$ ) and lactation ( $\leq$ 100 days of lactation and $\geq 100$ days of lactation). A "good and/or poor feed base region" 
was classified based on the availability of quantity and quality of roughages throughout the year to the animals.

\section{Site of the experiment}

The study was conducted in Baghabari at Shirajgonj district as good feed base (availability of good quality and adequate quantity roughages to the animals throughout the year) and Burirhat at Rangpur district as poor feed base (availability of poor quality and insufficient quantity of roughages to the animals throughout the year) regions for a period of 21 days in each season.

\section{Animal management}

Rice straw was offered ad libitum twice a day; first in the morning at 07:00 am and again in the evening at 6:00 pm. Green grass was also offered ad libitum twice a day; first in the morning at $8.30 \mathrm{am}$ and again in the evening at $4.30 \mathrm{pm}$. Concentrate mixture were supplied twice a day; first in the morning at 5.30 am and again in the evening at $4.00 \mathrm{pm}$ before milking. Fresh water was ensured twice a day (morning at 5.45 am and evening at $4.45 \mathrm{pm}$ ) during the experimental period, but the amount of water was not measured. Milking was done manually twice a day; first in the morning at 6.00 am and again in the evening at $5.00 \mathrm{pm}$. Cows were housed in individual stall on a concrete floor throughout the experimental period.

\section{Animal weighing and body condition score (BCS)}

Live weight of each cow was measured using a calibrated electronic digital scale (Baset et al.2010). BCS was assessed by palpating individual body parts, and an average score was recorded on a 5-point scale, where 1 was emaciated and 5 was obese (Wildman et al.1982).

\section{Measurement of feed intake and chemical composition}

Cows consumed all the concentrates but sometimes refused rice straw and green grasses. For measuring feed intake, rice straw and green grasses were weighed every day before supplying to the cow; next morning left over of straw and green grasses were weighed. Feed intake and refusals were recorded and analyzed for proximate component followed by the method of AOAC (2004). The values of rumen degradable protein (RDP) and rumen undegradable protein (UDP) were adopted from Kearl (1982), Singh \& Oosting (1993), Walli et al.(1993) and Khandaker and Tareque (1997). Energy values of roughages and concentrates were also adopted from Kearl (1982) and Singh \& Oosting (1993).

\section{Milk yield and composition}

The daily milk yield of individual cow was recorded and milk samples were collected from the morning and evening milking at the scheduled day in every week. Samples were 
preserved at $-20^{\circ} \mathrm{C}$ and carried out in the Dairy Science Laboratory of Animal Production Research Division (APRD), Bangladesh Livestock Research Institute (BLRI), Savar, Dhaka, and analyzed for fat, protein, lactose, SNF and minerals using a Milk Analyzer (LactoStar, Funke Gerber, Germany).

\section{Statistical analysis}

Data were analyzed in a $2 \times 2 \times 2 \times 2$ factorial experiment in Randomized Block Design (RBD) using a computer package GENSTAT (Lawes Agricultural Trust, 1997) to determine the treatment effects of mean.

\section{Results and discussion}

\section{Effects of feed base region on feed and nutrients intake of dairy cows}

The effects of feed base region on feed and nutrients intake of dairy cows are presented in Table 1. Feed intake of cows under good feed base region was higher than the intake of cows under poor feed base region. Daily dry matter intakes (DMI) of cows under good and poor feed base condition were 8.53 and $5.40 \mathrm{~kg}$, respectively. The roughage: concentrate ratio was significantly $(\mathrm{p}<0.01)$ higher in poor feed base $(2.64 \mathrm{~kg})$ compared to that of good feed base management condition $(1.61 \mathrm{~kg})$. Daily metabolizable energy (ME) intake of cows under good and poor feed base management condition were 70.23 MJ and 40.20 MJ, respectively. Where, M/D in good feed base $(8.24 \mathrm{MJ} / \mathrm{Kg} \mathrm{DM})$ was significantly $(\mathrm{p}<0.01)$ higher than that of the poor feed base management condition $(7.27 \mathrm{MJ} / \mathrm{kg} \mathrm{DM})$. The reasons of this behind may be the availability of quantity and quality of roughage and concentrate feeds in feed base regions.

Table 1. Effects of feed base region on feed and nutrients intake of dairy cows

\begin{tabular}{cccc}
\hline Parameters & \multicolumn{2}{c}{ Mean value } & $\begin{array}{c}\text { LSD }^{1} \text { and level of } \\
\text { significance }\end{array}$ \\
\cline { 2 - 3 } & $\begin{array}{c}\text { Good feed base } \\
\text { region }\end{array}$ & $\begin{array}{c}\text { Poor feed base } \\
\text { region }\end{array}$ & \\
\hline DM, kg/d & 8.53 & 5.40 & $0.45^{* *}$ \\
ME, MJ/d & 70.23 & 40.20 & $3.86^{* *}$ \\
CP, g/d & 839 & 386 & $50.0^{* *}$ \\
RDP, g/d & 488.5 & 166.0 & $32.95^{* *}$ \\
UDP, g/d & 350.9 & 220.0 & $19.79^{* *}$ \\
Ash, kg/d & 0.94 & 0.75 & $0.06^{* *}$ \\
OM, kg/d & 7.62 & 4.63 & $0.40^{* *}$ \\
ADF, kg/d & 2.92 & 1.25 & $0.15^{* *}$ \\
M/D, MJ/kgDM & 8.24 & 7.27 & $0.16^{* *}$ \\
Roughage: concentrate & $1.61: 1$ & $2.64: 1$ & $0.35^{* *}$ \\
Requirements (ARC, 1994) & & & \\
ME, MJ/d (req.) & 83.3 & 51.7 & $6.55^{* *}$ \\
Protein deficit, g/d & -270.0 & -164.5 & $18.30^{* *}$ \\
RDP, g/d (req.) & 650.0 & 403.0 & $51.1^{* *}$ \\
\hline
\end{tabular}

$* * P<0.01 ;{ }^{1} \mathrm{LSD}=$ least significant difference 
The requirements of ME (ARC, 1994) were 83.3 and $51.7 \mathrm{MJ} /$ day, respectively. The daily intake of Ash, organic matter (OM) and acid detergent fiber (ADF) were significantly $(p<0.01)$ higher in good feed base than that of the poor feed base condition. The intake of crude protein (CP), rumen degradable protein (RDP) and undegradable protein (UDP) were 839.0, 488.5 and $350.9 \mathrm{~g} / \mathrm{d}$, respectively in good feed base and 386.0, 166.0 and $220.0 \mathrm{~g} / \mathrm{d}$, respectively in poor feed base region. The daily protein intake as live weight and milk production in good and poor feed base management condition were significantly $(\mathrm{p}<0.01)$ lower (-270.0 and $-164.5 \mathrm{~g}$, respectively) than the requirements (ARC, 1994) and the daily RDP intake also were significantly $(\mathrm{p}<0.01)$ lower than the requirements (ARC, 1994).

\section{Effects of feed base region on live weight and body condition score (BCS)}

The effects of feed base (good and poor) region on live weight and body condition score (BCS) of dairy cows are presented in Table 2. The live weight and BCS of cows under good feed base management condition was higher than of the poor feed base management condition $(215.5 \mathrm{~kg})$. The live weight and BCS were $350.9 \mathrm{~kg}$ and 3.13, respectively in good feed base condition and $215.5 \mathrm{~kg}$ and 2.07 , respectively in poor feed base condition, which differed significantly $(\mathrm{p}<0.01)$. BCS of the cows of good feed base condition was 3.13 and poor feed base condition was 2.07 .

Table 2 .Effects of feed base region on live weight and body condition score (BCS)

\begin{tabular}{|c|c|c|c|}
\hline \multirow{2}{*}{ Parameters } & \multicolumn{2}{|c|}{ Mean value } & \multirow{2}{*}{$\begin{array}{l}\mathrm{LSD}^{1} \text { and level of } \\
\text { significance }\end{array}$} \\
\hline & $\begin{array}{l}\text { Good feed base } \\
\text { region }\end{array}$ & $\begin{array}{l}\text { Poor feed base } \\
\text { region }\end{array}$ & \\
\hline Live weight $(\mathrm{kg})$ & 350.9 & 215.5 & $14.02 * *$ \\
\hline BCS & 3.13 & 2.07 & $0.24 * *$ \\
\hline
\end{tabular}

$* * P<0.01 ;{ }^{1} \mathrm{LSD}=$ least significant difference

\section{Effects of feed base region on milk yield and composition of dairy cows}

The effects of feed base region on milk yield and composition of dairy cows are presented in Table 3. The milk yield and 4\% FCM (kg/d) of cows under the good feed base condition were higher than that of the poor feed base condition. Daily milk yield and 4\% FCM of cows under good feed base condition were 6.76 and $6.49 \mathrm{~kg}$, respectively and under poor feed base condition were 3.67 and $3.31 \mathrm{~kg}$, respectively, which differed significantly ( $<<0.01)$. Turki et al (2012) stated that milk yield was significantly $(\mathrm{p}<0.05)$ affected by the type of feed. This may be the differences of availability of quality and quantity of roughage feeds in good and poor feed base regions. 
Feed base region did not affect on the milk fat $(39.6 \& 37.3 \mathrm{~g} / \mathrm{kg}$ for good and poor feed base, respectively). The milk protein, lactose, solids-not-fat (SNF), minerals and total solids were influenced by feed base region. The milk protein, lactose, solids-not-fat (SNF), minerals and total solids under good feed base condition were 37.9, 54.9, 100.9, 6.3 and $140.6 \mathrm{~g} / \mathrm{kg}$, respectively and under poor feed base condition were $36.3,52.9,98.0,6.1$ and $135.2 \mathrm{~g} / \mathrm{kg}$, respectively, which were significantly $(\mathrm{p}<0.01)$ influenced by feed base region.

Table 3 .Effects of feed base region on milk yield and composition of dairy cows

\begin{tabular}{|c|c|c|c|}
\hline \multirow[t]{2}{*}{ Parameters } & \multicolumn{2}{|c|}{ Mean value } & \multirow{2}{*}{$\begin{array}{l}\mathrm{LSD}^{1} \text { and level of } \\
\text { significance }\end{array}$} \\
\hline & $\begin{array}{l}\text { Good feed base } \\
\text { region }\end{array}$ & $\begin{array}{l}\text { Poor feed base } \\
\text { region }\end{array}$ & \\
\hline \multicolumn{4}{|l|}{ Milk production } \\
\hline Milk yield, $\mathrm{kg} / \mathrm{d}$ & 6.76 & 3.67 & $0.75 * *$ \\
\hline $4 \% \mathrm{FCM}, \mathrm{kg} / \mathrm{d}$ & 6.49 & 3.31 & $0.73 * *$ \\
\hline \multicolumn{4}{|l|}{ Milk composition } \\
\hline Fat, g/kg & 39.6 & 37.3 & $2.5 \mathrm{NS}$ \\
\hline Protein, $\mathrm{g} / \mathrm{kg}$ & 37.9 & 36.3 & $0.8^{* *}$ \\
\hline Lactose, $\mathrm{g} / \mathrm{kg}$ & 54.9 & 52.9 & $1.2 * *$ \\
\hline $\mathrm{SNF}, \mathrm{g} / \mathrm{kg}$ & 100.9 & 98.0 & $2.3^{*}$ \\
\hline Minerals, g/kg & 6.3 & 6.1 & $0.2^{*}$ \\
\hline Total solids, $\mathrm{g} / \mathrm{kg}$ & 140.6 & 135.2 & $4.1^{*}$ \\
\hline
\end{tabular}

\section{Effects of season on feed and nutrients intake of dairy cows}

Daily DM and ME intake of cows in dry season were $7.00 \mathrm{~kg}$ and $54.69 \mathrm{MJ}$ and in wet season were $6.93 \mathrm{~kg}$ and $55.73 \mathrm{MJ}$ (Table 4). The CP and RDP intake of cows were higher in dry season compared to that of wet season due to shortage of quality and quantity of roughage feeds. Intake of $\mathrm{CP}$ and RDP in dry season was found 664 and $358.5 \mathrm{~g} / \mathrm{d}$, respectively and in the wet season it was 561 and $296 \mathrm{~g} / \mathrm{d}$, respectively, which differed significantly $(\mathrm{p}<0.01)$. The daily protein and RDP intake as per body weight and production in both season were below the requirement (ARC, 1994).

Table 4. Effects of season on feed and nutrients intake of dairy cows

\begin{tabular}{|c|c|c|c|}
\hline \multirow[t]{2}{*}{ Parameters } & \multicolumn{2}{|c|}{ Mean value } & \multirow{2}{*}{$\begin{array}{c}\mathrm{LSD}^{1} \text { and level of } \\
\text { significance }\end{array}$} \\
\hline & Dry season & Wet season & \\
\hline $\mathrm{DM}, \mathrm{kg} / \mathrm{d}$ & 7.00 & 6.93 & $0.45 \mathrm{NS}$ \\
\hline $\mathrm{ME}, \mathrm{MJ} / \mathrm{d}$ & 54.69 & 55.73 & $3.86 \mathrm{NS}$ \\
\hline $\mathrm{CP}, \mathrm{g} / \mathrm{d}$ & 664 & 561 & $50.0^{* *}$ \\
\hline RDP, g/d & 358.5 & 296.0 & $32.95 * *$ \\
\hline UDP, g/d & 305.6 & 265.4 & $19.79 * *$ \\
\hline Ash, kg/d & 0.76 & 0.93 & $0.06^{* *}$ \\
\hline $\mathrm{OM}, \mathrm{kg} / \mathrm{d}$ & 6.27 & 5.98 & $0.40 \mathrm{NS}$ \\
\hline $\mathrm{ADF}, \mathrm{kg} / \mathrm{d}$ & 2.60 & 1.57 & $0.15^{* *}$ \\
\hline
\end{tabular}




\begin{tabular}{lccc}
\hline M/D, MJ/kgDM & 7.61 & 7.90 & $0.16^{* *}$ \\
Roughage: concentrate & 2.15 & 2.10 & $0.35 \mathrm{NS}$ \\
Requirements (ARC, 1994) & & & \\
ME, MJ/d (req.) & 66.1 & 68.9 & $6.55 \mathrm{NS}$ \\
Protein deficit, g/d & -237.3 & -197.2 & $18.30^{* *}$ \\
RDP, g/d (req.) & 515.0 & 538.0 & $51.1 \mathrm{NS}$ \\
\hline
\end{tabular}

$\mathrm{NS}=$ not significant, $* P<0.05, * * P<0.01 ;{ }^{1} \mathrm{LSD}=$ least significant difference

\section{Effects of season on live weight and body condition score (BCS) of dairy cows}

The effects of season on live weight and BCS of dairy cows are presented in Table 5. Seasons did not influence the live weight of cows but, it influenced the BCS of the animals. The live weight of cow was $284.0 \mathrm{~kg}$ in the dry season and in the winter season $282.3 \mathrm{~kg}$ which did not differ significantly ( $\mathrm{p}>0.05$ ). But, the body condition score (BCS) between dry season and wet season (2.74 vs. $2.46 \mathrm{~kg})$ differed significantly $(\mathrm{p}<0.05)$.

Table 5. Effects of season on live weight and body condition score (BCS) of dairy cows

\begin{tabular}{|c|c|c|c|}
\hline \multirow[t]{2}{*}{ Parameters } & \multicolumn{2}{|c|}{ Mean value } & \multirow{2}{*}{$\begin{array}{c}\text { LSD }^{1} \text { and level of } \\
\text { significance }\end{array}$} \\
\hline & Dry season & Wet season & \\
\hline Live weight (kg) & 284.0 & 282.3 & $14.02 \mathrm{NS}$ \\
\hline BCS & 2.74 & 2.46 & $0.24^{*}$ \\
\hline
\end{tabular}

\section{Effects of season on milk yield and composition of dairy cows}

The effects of season on milk yield and composition of dairy cows are presented in Table 6. Season did not affect milk yield and 4\%FCM and it also did not affect milk quality except minerals $(6.5 \mathrm{~g} / \mathrm{kg}$ vs. $5.9 \mathrm{~g} / \mathrm{kg})$. Sharma et al., (2002) found that the overall mean for fat, TS and SNF content of milk yield were 4.53, 13.31 and 8.75 per cent, respectively. He also reported that SNF and TS content varied among seasons being highest in winter $(8.98 \%$ and $13.64 \%)$ followed by summer $(8.83 \%$ and $13.40 \%)$ and lowest in rainy season $(8.44 \%$ and 12.88\%). Heck et al., (2009) found that milk lactose concentration was rather constant throughout the season. Milk true protein content was somewhat more responsive to season, with the lowest content in June $(3.21 \mathrm{~g} / 100 \mathrm{~g})$ and the highest content in December $(3.38$ $\mathrm{g} / 100 \mathrm{~g}$ ). Milk fat concentration increased from a minimum of $4.10 \mathrm{~g} / 100 \mathrm{~g}$ in June to a maximum of $4.57 \mathrm{~g} / 100 \mathrm{~g}$ in January. Cows in spring and winter produced more milk over 1.43 and $0.93 \mathrm{~kg} /$ day, respectively, than cows in summer (Yoon et al.2004). 
Table 6. Effects of season on milk yield and composition of dairy cows

\begin{tabular}{|c|c|c|c|}
\hline \multirow[t]{2}{*}{ Parameters } & \multicolumn{2}{|c|}{ Mean value } & \multirow{2}{*}{$\begin{array}{l}\text { LSD }^{1} \text { and level of } \\
\text { significance }\end{array}$} \\
\hline & Dry season & Wet season & \\
\hline \multicolumn{4}{|l|}{ Milk production } \\
\hline Milk yield, kg/d & 5.27 & 5.17 & $0.75 \mathrm{NS}$ \\
\hline $4 \% \mathrm{FCM}, \mathrm{kg} / \mathrm{d}$ & 4.90 & 4.90 & $0.73 \mathrm{NS}$ \\
\hline \multicolumn{4}{|l|}{ Milk composition } \\
\hline Fat, g/kg & 39.6 & 37.3 & $2.5 \mathrm{NS}$ \\
\hline Protein, $\mathrm{g} / \mathrm{kg}$ & 37.1 & 37.2 & $0.8 \mathrm{NS}$ \\
\hline Lactose, $\mathrm{g} / \mathrm{kg}$ & 53.7 & 54.0 & $1.2 \mathrm{NS}$ \\
\hline $\mathrm{SNF}, \mathrm{g} / \mathrm{kg}$ & 99.7 & 99.2 & $2.3 \mathrm{NS}$ \\
\hline Minerals, g/kg & 6.5 & 5.9 & $0.2 * *$ \\
\hline Total solids, $\mathrm{g} / \mathrm{kg}$ & 139.3 & 136.5 & $4.1 \mathrm{NS}$ \\
\hline
\end{tabular}

\section{Effects of genotype on feed and nutrients intake of dairy cows}

The effects of genotype on feed and nutrients intake of dairy cows are presented in Table 7. Daily feed intake of crossbred cow was higher than the local cow due to its higher live weight and BCS. The daily DMI of local cow was $5.75 \mathrm{~kg}$ and crossbred cow was $8.17 \mathrm{~kg}$, which differed significantly $(\mathrm{p}<0.01)$; but, the roughage/concentrate ratio of local cow (2.65) was significantly $(\mathrm{p}<0.01)$ higher than crossbred cow (1.60). Daily ME intake of crossbred cow (64.82 MJ) was significantly ( $\mathrm{p}<0.01)$ higher than local cow $(45.60 \mathrm{MJ})$, which were lowered compared to the requirement as per ARC (1994). The intake of crossbred cow was higher than of the local cow. Daily CP, RDP and UDP intake of crossbred cow were 708, 378 and $330 \mathrm{~g}$, respectively and of local cow were 517, 276 and $240 \mathrm{~g}$, respectively; which differed significantly ( $\mathrm{p}<0.01)$, but, below the requirement (ARC, 1994). Energy/protein ratio in local cow (0.10) and crossbred cow (0.09) were not-significant.

Table 7. Effects of genotype on feed and nutrients intake of dairy cows

\begin{tabular}{|c|c|c|c|}
\hline \multirow[t]{2}{*}{ Parameters } & \multicolumn{2}{|c|}{ Mean value } & \multirow{2}{*}{$\begin{array}{c}\text { LSD }^{1} \text { and level of } \\
\text { significance }\end{array}$} \\
\hline & Local cow & Crossbred cow & \\
\hline $\mathrm{DM}, \mathrm{kg} / \mathrm{d}$ & 5.75 & 8.17 & $0.45 * *$ \\
\hline $\mathrm{ME}, \mathrm{MJ} / \mathrm{d}$ & 45.60 & 64.82 & $3.86^{* *}$ \\
\hline $\mathrm{CP}, \mathrm{g} / \mathrm{d}$ & 517 & 708 & $50.0 * *$ \\
\hline RDP, g/d & 276.4 & 378.0 & $32.95 * *$ \\
\hline UDP, g/d & 240.6 & 330.4 & $19.79 * *$ \\
\hline Ash, kg/d & 0.71 & 0.98 & $0.06^{* *}$ \\
\hline $\mathrm{OM}, \mathrm{kg} / \mathrm{d}$ & 5.04 & 7.21 & $0.40 * *$ \\
\hline $\mathrm{ADF}, \mathrm{kg} / \mathrm{d}$ & 1.77 & 2.40 & $0.15^{* *}$ \\
\hline $\mathrm{M} / \mathrm{D}, \mathrm{MJ} / \mathrm{kg} \mathrm{DM}$ & 7.60 & 7.91 & $0.16^{* *}$ \\
\hline Roughage: concentrate & 2.65 & 1.60 & $0.35 * *$ \\
\hline
\end{tabular}




\begin{tabular}{lccc}
\hline Requirements & & & \\
ME, MJ/d (req.) & 55.0 & 80.0 & $6.55^{* *}$ \\
Protein deficit, g/d & -179.4 & -255.2 & $18.30^{* *}$ \\
RDP, g/d (req.) & 429.0 & 624.0 & $51.1^{* *}$ \\
\hline
\end{tabular}

$* P<0.05, * * P<0.01 ;{ }^{1} \mathrm{LSD}=$ least significant difference

\section{Effects of genotype on live weight and body condition score (BCS) of dairy cows}

The effects of genotypes (local and crossbred cow) on live weight, BCS and feed and nutrients intake of dairy cows is presented in Table 8 . The live weight and BCS of crossbred cows was higher than that of the local cows. The live weight and BCS of crossbred cow were $318.8 \mathrm{~kg}$ and 2.85, respectively and of local cow were $247.5 \mathrm{~kg}$ and 2.34 , respectively, which was significantly $(\mathrm{p}<0.01)$ different than crossbred cow.

Table 8 . Effects of genotype on live weight and body condition score (BCS) of dairy cows

\begin{tabular}{lccc}
\hline Parameters & \multicolumn{2}{c}{ Mean value } & \multirow{2}{*}{$\begin{array}{c}\text { SSD }^{1} \text { and level of } \\
\text { significance }\end{array}$} \\
\cline { 2 - 2 } & Local cow & Crossbred cow & \\
\hline Live weight $(\mathrm{kg})$ & 247.5 & 318.8 & $14.02^{* *}$ \\
BCS & 2.34 & 2.85 & $0.24 * *$ \\
\hline$* P<0.05, * * P<0.01 ;{ }^{1} \mathrm{LSD}=$ least significant difference & &
\end{tabular}

\section{Effects of genotype on milk yield and composition of dairy cows}

The effects of genotype on milk yield and composition of dairy cows are presented in Table 9. Milk yield of local cows were lower than crossbred cows. Daily milk yield and 4\%FCM of local cows were 3.26 and $3.28 \mathrm{~kg}$, respectively and of crossbred cows were 7.18 and $6.52 \mathrm{~kg}$, respectively, which differed significantly $(\mathrm{p}<0.01)$. The milk protein of local cows was higher than the crossbred cows. The milk protein of local cow was $37.3 \mathrm{~g} / \mathrm{kg}$ and of crossbred cow was $37.0 \mathrm{~g} / \mathrm{kg}$, which differed significantly $(\mathrm{p}<0.01)$. Genotype had a significant effect on all milk production parameters, high merit cows had the highest yield of milk, fat, protein, and lactose, whereas the low merit cows had the lowest milk fat, protein, and lactose concentrations (Kennedy et al., 2003 and Turki et al.2012).

Table 9 . Effects of genotype on milk yield and composition of dairy cows

\begin{tabular}{|c|c|c|c|}
\hline \multirow[t]{2}{*}{ Parameters } & \multicolumn{2}{|c|}{ Mean value } & \multirow{2}{*}{$\begin{array}{c}\mathrm{LSD}^{1} \text { and level of } \\
\text { significance }\end{array}$} \\
\hline & Local cow & Crossbred cow & \\
\hline \multicolumn{4}{|l|}{ Milk production } \\
\hline Milk yield, kg/d & 3.26 & 7.18 & $0.75^{* *}$ \\
\hline 4\%FCM, kg/d & 3.28 & 6.52 & $0.73 * *$ \\
\hline \multicolumn{4}{|l|}{ Milk composition } \\
\hline Fat, $\mathrm{g} / \mathrm{kg}$ & 39.5 & 37.3 & $2.5 \mathrm{NS}$ \\
\hline Protein, g/kg & 37.3 & 37.0 & $0.8 * *$ \\
\hline Lactose, $\mathrm{g} / \mathrm{kg}$ & 54.0 & 53.8 & $1.2 \mathrm{NS}$ \\
\hline
\end{tabular}




\begin{tabular}{cccc}
\hline SNF, g/kg & 94.0 & 98.9 & $2.3 \mathrm{NS}$ \\
Minerals, g/kg & 6.1 & 6.3 & $0.2^{* *}$ \\
Total solids, g/kg & 139.5 & 136.3 & $4.1 \mathrm{NS}$ \\
\hline NS = not significant, ${ }^{* *} P<0.01 ;{ }^{1} \mathrm{LSD}=$ least significant difference
\end{tabular}

Table 10. Effects of lactation on feed and nutrients intake of dairy cows

\begin{tabular}{lccc}
\hline Parameters & \multicolumn{2}{c}{ Mean value } & $\begin{array}{c}\text { LSD }^{1} \text { and level of } \\
\text { significance }\end{array}$ \\
\cline { 2 - 3 } & $\begin{array}{c}\leq 100 \text { days of } \\
\text { lactation }\end{array}$ & $\begin{array}{c}\geq 100 \text { days of } \\
\text { lactation }\end{array}$ & \\
\hline DM, kg/d & 6.50 & 7.42 & $0.45^{* *}$ \\
Roughage: concentrate & 2.26 & 1.99 & $0.35 \mathrm{NS}$ \\
ME, MJ/d & 51.88 & 58.55 & $3.86^{* *}$ \\
M/D, MJ/KgDM & 7.79 & 7.73 & $0.16 \mathrm{NS}$ \\
CP, g/d & 584.0 & 641.0 & $50.0^{*}$ \\
RDP, g/d & 316.0 & 338.5 & $32.95 \mathrm{NS}$ \\
UDP, g/d & 268.5 & 302.5 & $19.79^{* *}$ \\
Ash, $\mathrm{kg} / \mathrm{d}$ & 0.79 & 0.91 & $0.06^{* *}$ \\
OM, kg/d & 5.73 & 6.52 & $0.40^{* *}$ \\
ADF, kg/d & 1.97 & 2.20 & $0.15^{* *}$ \\
Requirements & & & \\
ME, MJ/d (req.) & 60.8 & 74.2 & $6.55^{* *}$ \\
Protein deficit, g/d & -202.2 & -232.4 & $18.30^{* *}$ \\
RDP, g/d (req.) & 474.0 & 579.0 & $51.1^{* *}$ \\
\hline
\end{tabular}

$\mathrm{NS}=$ not significant, $* P<0.05, * * P<0.01 ;{ }^{1} \mathrm{LSD}=$ least significant difference

\section{Effects of lactation on feed and nutrients intake}

Effects of lactation on feed and nutrients intake of dairy cows are presented in Table 10. Lactation affects the daily feed and nutrients intake of cow. Daily DMI at $\leq 100$ lactation of cow was $6.50 \mathrm{~kg}$ and at $\geq 100$ lactation of cow was $7.42 \mathrm{~kg}$, which differed significantly $(\mathrm{p}<0.01)$; but, the roughage: concentrate ratio was not significant. Daily ME intake at $\leq 100$ lactation of cow was $51.88 \mathrm{MJ}$ and at $\geq 100$ lactation of cow was $58.55 \mathrm{MJ}$, which differed significantly ( $\mathrm{p}<0.01$ ); but, lowered compare to requirements (ARC, 1994). Daily CP, RDP and UDP intake at $\leq 100$ days of lactation of cow were 584.0, 316.0 and $268.5 \mathrm{~g}$, respectively and at $\geq 100$ days of lactation of cow were $641.0,338.5$ and $302.5 \mathrm{~g}$, respectively; which were below the requirements (ARC, 1994). The intake of CP and UDP were differed significantly ( $\mathrm{p}<0.01$ ); but, RDP intake was not significant. The energy: protein ratio was not differed significantly. The daily intake of Ash, organic matter (OM) and acid detergent fiber (ADF) were significantly $(\mathrm{p}<0.01)$ higher at $\geq 100$ days of lactation of cow than that of at $\leq 100$ days of lactation of cow. The intake of Ash, OM and ADF were 0.91, 6.52 and 2.20 $\mathrm{kg} / \mathrm{d}$, respectively at $\geq 100$ days of lactation of cow and $0.79,5.73$ and $1.97 \mathrm{~kg} / \mathrm{d}$, respectively at $\leq 100$ days of lactation of cow. 


\section{Effects of lactation on live weight and body conditions score (BCS) of dairy cows}

The effects of lactation ( $\leq 100$ days of lactation and $\geq 100$ days of lactation) on live weight and BCS of dairy cows is presented in Table 11. Results indicated that lactation affect the live weight and but does not affect BCS of cows. Live weight and BCS were $272.7 \mathrm{~kg}$ and 2.50 , respectively at $\leq 100$ days of lactation and $293.7 \mathrm{~kg}$ and 2.69 , respectively at $\geq 100$ days of lactation, where live weight was found statistically significant $(\mathrm{p}<0.01)$ but, BCS was not significant.

Table 11. Effects of lactation on live weight, body condition score (BCS) of dairy cows

\begin{tabular}{lccc}
\hline Parameters & \multicolumn{2}{c}{ Mean value } & $\begin{array}{c}\text { LSD }^{1} \text { and level of } \\
\text { significance }\end{array}$ \\
\cline { 2 - 3 } & $\begin{array}{c}\leq 100 \text { days of } \\
\text { lactation }\end{array}$ & $\begin{array}{c}\geq 100 \text { days of } \\
\text { lactation }\end{array}$ & \\
\hline Live weight $(\mathrm{kg})$ & 272.7 & 293.7 & $14.02^{* *}$ \\
BCS & 2.50 & 2.69 & $0.24 \mathrm{NS}$ \\
\hline
\end{tabular}

$\mathrm{NS}=$ not significant, $* * P<0.01 ;{ }^{1} \mathrm{LSD}=$ least significant difference

\section{Effects of lactation on milk yield and composition of dairy cows}

The effects of lactation on milk yield and composition of dairy cows are presented in Table 12. Lactation did not affect milk yield, $4 \% \mathrm{FCM}$ and the milk protein, but, affected the fat, lactose, SNF, minerals and total solids. The daily milk yield of cow was $5.33 \mathrm{~kg}$ at $\leq 100$ days of lactation and $5.10 \mathrm{~kg}$ at $\geq 100$ days of lactation. The milk fat, protein, lactose, SNF, minerals and total solids were $34.6,36.5,53.1,98.0,6.1$ and $132.6 \mathrm{~g} / \mathrm{kg}$, respectively at $\leq 100$ days of lactation and 42.3, 37.8, 54.7, 100.9, 6.3 and $143.2 \mathrm{~g} / \mathrm{kg}$, respectively at $\geq 100$ days of lactation, which differed significantly $(\mathrm{p} \leq 0.01)$. Yoon et al, (2004) reported that milk yield was linearly decreased as lactation increased while milk fat and protein contents were linearly increased $(\mathrm{p}<0.01)$.

\section{Interaction of feed base regions and seasons on milk yield and composition of dairy cows}

Interaction of feed base regions and seasons on milk yield and composition of dairy cows is presented in Table 13. Result showed that interaction of feed base regions and seasons significantly influenced milk yield and the milk fat and SNF. Table 14 shows that the interaction of feed base regions, seasons and lactation affected the milk protein and lactose.

Some milk constituents are strongly correlated (Table 15). Milk yield negatively correlated with fat\% $(r=-0.14)$, protein $\%(r=-0.036)$, lactose $\%(r=-0.041)$ and SNF\% $(r=-0.065)$. Fat $\%$ significantly $(\mathrm{p} \leq 0.01)$ correlated with protein $\%(r=0.506)$, lactose $\%(r=0.442)$, SNF\% $(r=0.481)$ and minerals $\%(r=0.270)$. Protein $\%$ correlated with lactose $\%(r=0.890)$, 
SNF\% $(r=0.882)$ and minerals $(r=0.240)$. Lactose $\%$ significantly $(p \leq 0.01)$ correlated with

SNF\% $(r=0.895)$.

Table 12. Effects of lactation on milk yield and composition of dairy cows

\begin{tabular}{lccc}
\hline Parameters & \multicolumn{2}{c}{ Mean value } & $\begin{array}{c}\text { LSD }^{1} \text { and level of } \\
\text { significance }\end{array}$ \\
\cline { 2 - 3 } & $\begin{array}{c}\leq 100 \text { days of } \\
\text { lactation }\end{array}$ & $\begin{array}{c}\geq 100 \text { days of } \\
\text { lactation }\end{array}$ & \\
\hline Milk production & 5.33 & 5.10 & $0.75 \mathrm{NS}$ \\
Milk yield, kg/d & 4.61 & 5.19 & $0.73 \mathrm{NS}$ \\
4\%FCM, kg/d & & & \\
Milk composition & 34.6 & 42.3 & $2.5^{* *}$ \\
Fat, g/kg & 36.5 & 37.8 & $0.8 \mathrm{NS}$ \\
Protein, g/kg & 53.1 & 54.7 & $1.2^{* *}$ \\
Lactose, g/kg & 98.0 & 100.9 & $2.3^{*}$ \\
SNF, g/kg & 6.1 & 6.3 & $0.2^{*}$ \\
Minerals, g/kg & 132.6 & 143.2 & $4.1^{* *}$ \\
Total solids, g/kg & . & & \\
\hline
\end{tabular}

$\mathrm{NS}=$ not significant, $* P<0.05, * * P<0.01 ;{ }^{1} \mathrm{LSD}=$ least significant difference

Table 13 .Interaction of feed base regions and seasons on milk yield and composition of dairy cows

\begin{tabular}{lcccccccc}
\hline Interactions & $\begin{array}{c}\mathrm{MY}, \\
\mathrm{kg} / \mathrm{d}\end{array}$ & $\begin{array}{c}4 \% \mathrm{FCM}, \\
\mathrm{kg} / \mathrm{d}\end{array}$ & $\begin{array}{c}\text { Fat, } \\
\mathrm{g} / \mathrm{kg}\end{array}$ & $\begin{array}{c}\text { Protein, } \\
\mathrm{g} / \mathrm{kg}\end{array}$ & $\begin{array}{c}\text { Lactose, } \\
\mathrm{g} / \mathrm{kg}\end{array}$ & $\begin{array}{c}\mathrm{SNF}, \\
\mathrm{g} / \mathrm{kg}\end{array}$ & $\begin{array}{c}\text { Minerals, } \\
\mathrm{g} / \mathrm{kg}\end{array}$ & $\begin{array}{c}\text { Total } \\
\text { solids, } \\
\mathrm{g} / \mathrm{kg}\end{array}$ \\
\hline $\mathrm{R} 1 \times \mathrm{S} 1$ & 7.39 & 6.66 & 38.4 & 37.5 & 54.2 & 100.0 & 6.5 & 138.5 \\
$\mathrm{R} 1 \times \mathrm{S} 2$ & 6.13 & 6.32 & 40.8 & 38.3 & 55.5 & 101.8 & 6.0 & 142.6 \\
$\mathrm{R} 2 \times \mathrm{S} 1$ & 3.15 & 3.13 & 40.8 & 36.6 & 53.3 & 99.4 & 6.5 & 140.2 \\
$\mathrm{R} 2 \times \mathrm{S} 2$ & 4.20 & 3.49 & 33.8 & 36.0 & 52.6 & 96.6 & 5.7 & 130.3 \\
$\mathrm{SED}$ & - & 0.52 & - & 0.6 & 0.8 & - & - & - \\
LSD & 1.06 & - & 3.6 & - & - & 3.2 & 0.2 & 5.7 \\
Level of & $* *$ & $\mathrm{NS}$ & $* *$ & $\mathrm{NS}$ & $\mathrm{NS}$ & $*$ & $*$ & $* *$ \\
significance & & & & & & & & \\
\hline
\end{tabular}

$\mathrm{R}_{1}=$ Good feed base region, $\mathrm{R}_{2}=$ Poor feed base region, $\mathrm{S}_{1}=$ Dry season and $\mathrm{S}_{2}=$ Wet season.

$\mathrm{NS}=$ not significant, $* P<0.05, * * P<0.01,{ }^{1} \mathrm{LSD}=$ least significant difference 
Table 14. Interactions of feed base, seasons and lactation on milk yield and composition of dairy cows

\begin{tabular}{|c|c|c|c|c|c|c|c|c|}
\hline Interactions & $\begin{array}{l}\mathrm{MY}, \\
\mathrm{kg} / \mathrm{d}\end{array}$ & $\begin{array}{c}4 \% \mathrm{FCM} \\
\mathrm{kg} / \mathrm{d}\end{array}$ & $\begin{array}{l}\text { Fat, } \\
\mathrm{g} / \mathrm{kg}\end{array}$ & $\begin{array}{l}\text { Protein, } \\
\mathrm{g} / \mathrm{kg}\end{array}$ & $\begin{array}{l}\text { Lactose, } \\
\mathrm{g} / \mathrm{kg}\end{array}$ & $\begin{array}{l}\text { SNF, } \\
\mathrm{g} / \mathrm{kg}\end{array}$ & $\begin{array}{l}\text { Minerals, } \\
\mathrm{g} / \mathrm{kg}\end{array}$ & $\begin{array}{c}\text { Total } \\
\text { solids, } \\
\mathrm{g} / \mathrm{kg}\end{array}$ \\
\hline $\mathrm{R} 1 \times \mathrm{S} 1 \times \mathrm{L} 1$ & 8.13 & 6.83 & 35.1 & 37.3 & 54.0 & 100.0 & 6.5 & 135.1 \\
\hline $\mathrm{R} 1 \times \mathrm{S} 1 \times \mathrm{L} 2$ & 6.66 & 6.50 & 41.8 & 37.7 & 51.4 & 100.1 & 6.5 & 141.9 \\
\hline $\mathrm{R} 1 \times \mathrm{S} 2 \times \mathrm{L} 1$ & 6.32 & 5.82 & 36.1 & 37.4 & 54.4 & 99.1 & 6.0 & 135.1 \\
\hline $\mathrm{R} 1 \times \mathrm{S} 2 \times \mathrm{L} 2$ & 5.95 & 6.82 & 45.6 & 39.2 & 55.1 & 104.5 & 6.1 & 150.1 \\
\hline $\mathrm{R} 2 \times \mathrm{S} 1 \times \mathrm{L} 1$ & 3.12 & 3.01 & 37.5 & 35.1 & 54.3 & 96.4 & 6.2 & 133.9 \\
\hline $\mathrm{R} 2 \times \mathrm{S} 1 \times \mathrm{L} 2$ & 3.17 & 3.25 & 44.0 & 38.2 & 52.4 & 102.4 & 6.7 & 146.5 \\
\hline $\mathrm{R} 2 \times \mathrm{S} 2 \times \mathrm{L} 1$ & 3.76 & 2.79 & 29.8 & 36.0 & 56.7 & 96.7 & 5.7 & 126.4 \\
\hline $\mathrm{R} 2 \times \mathrm{S} 2 \times \mathrm{L} 2$ & 4.64 & 4.18 & 37.8 & 36.0 & 52.7 & 96.5 & 5.7 & 134.2 \\
\hline SED & 0.76 & 0.74 & 2.6 & - & - & 2.3 & 0.2 & 4.1 \\
\hline $\mathrm{LSD}^{1}$ & - & - & - & 0.17 & 02.3 & - & - & - \\
\hline $\begin{array}{l}\text { Level of } \\
\text { significance }\end{array}$ & NS & NS & NS & $* *$ & $*$ & NS & NS & NS \\
\hline
\end{tabular}

Table 15. Correlations coefficient among milk yield and composition

\begin{tabular}{|c|c|c|c|c|c|c|c|c|}
\hline & $\begin{array}{c}\text { MY } \\
(\mathrm{kg} / \mathrm{d})\end{array}$ & $\begin{array}{c}4 \% \mathrm{FCM} \\
(\mathrm{kg} / \mathrm{d})\end{array}$ & Fat $\%$ & Protein $\%$ & Lactose $\%$ & $\mathrm{SnF} \%$ & minerals $\%$ & $\begin{array}{c}\text { Total } \\
\text { Solids } \%\end{array}$ \\
\hline MY (kg/d) & 1 & & & & & & & \\
\hline \multirow[t]{2}{*}{$4 \% \mathrm{FCM}(\mathrm{kg} / \mathrm{d})$} & $.909(* *)$ & 1 & & & & & & \\
\hline & .000 & . & & & & & & \\
\hline \multirow[t]{2}{*}{ Fat $\%$} & -.140 & $.205(* *)$ & 1 & & & & & \\
\hline & .078 & .009 & . & & & & & \\
\hline \multirow[t]{2}{*}{ Protein $\%$} & -.036 & .130 & $.506(* *)$ & 1 & & & & \\
\hline & .654 & .101 & .000 & . & & & & \\
\hline \multirow[t]{2}{*}{ Lactose $\%$} & -.041 & .114 & $.442(* *)$ & $.890(* *)$ & 1 & & & \\
\hline & .602 & .150 & .000 & .000 & . & & & \\
\hline \multirow[t]{2}{*}{$\mathrm{SnF} \%$} & -.065 & .094 & $.481(* *)$ & $.882(* *)$ & $.895(* *)$ & 1 & & \\
\hline & .412 & .235 & .000 & .000 & .000 & . & & \\
\hline \multirow[t]{2}{*}{ Minerals\% } & .118 & .152 & $.270(* *)$ & $.240(* *)$ & $.175(*)$ & $.238(* *)$ & 1 & \\
\hline & .142 & .059 & .001 & .003 & .029 & .003 & . & \\
\hline \multirow[t]{2}{*}{ Total Solids\% } & -.124 & $.181(*)$ & $.891(* *)$ & $.781(* *)$ & $.747(* *)$ & $.826(* *)$ & $.296(* *)$ & 1 \\
\hline & .119 & .022 & .000 & .000 & .000 & .000 & .000 & . \\
\hline
\end{tabular}

** Correlation is significant at the 0.01 level (2-tailed);* Correlation is significant at the 0.05 level (2tailed) 


\section{Conclusion}

Results of the experiment shows that milk yield and composition of cows depends on feed base region, genotype and lactation. Season did not influence milk yield and composition. Milk yield negatively correlated with the percentage of fat, protein, lactose and SNF. The percentage of fat correlated with the percentage of protein, lactose, SNF, and minerals. The percentage of protein is correlated with the percentage of lactose, SNF and minerals. The percentage of lactose concentration significantly $(\mathrm{p} \leq 0.01)$ correlated with the percentage of SNF. The interaction of feed base regions and seasons significantly influenced milk yield and the milk fat and SNF, but the interaction of feed base regions, seasons and lactation affected the milk protein and lactose.

\section{Acknowledgment}

This work was financed by Bangladesh Livestock Research Institutes (BLRI), Dhaka. The authors thank to the staff of the BLRI for their cooperation and support.

\section{References}

AOAC. 2004. Official Methods of Analysis, Centennial Edition. Association of Official Analytical Chemist, Washington DC.

ARC. 1994. The Nutrient Requirements of Ruminant Livestock. Commonwealth Agricultural Bureau. Slough. England.

Auldist, M.J., Walsh, B.J. and Thomson, N.A. 1998. Seasonal and lactational influences on bovine milk composition in Newzealand. J. Dairy Sci., 65(3):401-408.

Baset, M.A., Huque, K.S., Sarker, N.R. and Hossain, M.M. 2010. Digital weighing of farm animals and calculation of nutritional requirements. Bangladesh J. Lives. Res., 17 (1\&2):60-64.

Delgado, C., Rosegrant, M., Ehui, S and Courbois, C. 1999. Livestock to 2020: The next Food Revolution. Food, Agriculture and Environment Discussion Paper 28, IFPRI/FAO/ILRI, IFPRI Washington DC.

DLS (Department of Livestock Services). 2008. Annual report on livestock, Division of Livestock Statistics, Ministry of Fisheries and Livestock, Farmgate, Dhaka, Bangladesh.

Hang, K.F., Hayes, J.F, Moxley, J.E. and Monardes, H.G. 1982. Environmental influences on protein content and composition of bovine milk. J. Dairy Sci. 65(10):1993-1998.

Haque, S.A.M. 2009. Bangladesh: Social gains from dairy development. In: Animal Production and Health Commission for Asia and the Pacific and Food and Agriculture Organization 
(APHCA-FAO) publication on smallholder dairy development: Lessons learned in Asia, RAP publication 2009/2.

Heck, J.M.L., Valenberg, H.J.F, Dijkstra, J. and Hooijdonk, A.C.M. 2009. Seasonal variation in the Dutch bovine raw milk composition. J. Dairy Sci., 92:4745-4755.

Hemme, T. 2008. Dairy Report. International Farm Comparison Network (IFCN). IFCN Dairy Research Center. Kiel Germany.

Huque, K.S., Rahman, M.M. and Islam, M.R. 2002. Farming characteristics of cooperative dairy production systems in Bangladesh. Bang. J. Livs. Res. 9 (1 \& 2):17-29.

Hussain, M.M., Ser-Od, T. and Dugdill, B. 2008. Selected smallholder dairying experiences from Bangladesh and Mongolia. Proceedings of Asia-Pacific smallholder dairy strategy workshop, Chiangmai, Thailand, 25-29 February, 2008.

Kearl, L.C. 1982. Nutrient requirements of ruminants in developing countries. International Feedstuffs Institute, Utah Agricultural Experiment Station, Utah State University, Logan Utah.

Kennedy, J., Dillon, P., Delaby, L., Faverdin, P., Stakelum, G. and Rath, M. 2003. Effect of genetic merit and concentrate supplementation on grass intake and milk production with Holstein Friesian dairy cows. J. Dairy Sci., 86(2):610-621.

Khandaker, Z.H. and Tareque, A.M.M. 1997. Effect of rumen degradable protein (RDP) in straw based ration on purine derivatives excretion and microbial nitrogen supply in cattle. AsianAust. J. Anim. Sci., 10(4):364-370.

Lawes Agricultural Trust. 1997. A General Statistical Programme. Genstat 5. 5th Edn. (Beta), Rothamsted Exptl. Stat., Harpenden, Hertfordshire, UK.

Mackle, T.R., Bryant, A.M., Petch, S.F., Hill J.P. and Auldist, M.J. 1999. Nutritional influences on the composition of milk from cows of different phenotypes in Newzealand. J. Dairy Sci., 82(1):172-180.

Miyan, H.A. 1996. Towards sustainable development: The national conservation strategy of Bangladesh. Consultancy report on the livestock sector. Ministry of Environment and Forestry, Dhaka, Bangladesh.

Ndambi, O.A., Hemme, T. and Latacz-Lohmann, U. 2007. Dairying in Africa - Status and recent developments. Livestock Research for Rural Development, 19:111.

Saadullah, M. 2001. Smallholder dairy production and marketing in Bangladesh. In: Smallholder dairy production and marketing-opportunities and constraints; Proceedings of a South-South workshop held at National Dairy Development Board (NDDB) Anand, India. 
Shamsuddin, M., Alam, M.M., Hossein, M.S., Goodger, W.J., Bari, F.Y., Ahmed, T.U., Hossain, M.M. and Khan, A.H.M.S.I. 2007. Participatory rural appraisal to identify needs and prospects of market-oriented dairy industries in Bangladesh. Trop. Anim. Health and Prod., 39:567-581.

Sharma, R.B. and Agarwal, J.P. 1985. Influence of stage of lactation on the chemical composition of cross-bred cows milk. J. Agric. Sci. Res., 27:11-14.

Sharma, R.B., Kumar, M. and Pathak, V. 2002. Effect of different seasons on cross-bred cow milk composition and paneer yield in sub-himalayan region. Asian-Aust. J. Anim. Sci., 15(4):528530.

Singh, G.P. and Oosting, S.J. 1993. Nutritive value of straw. In: Feeding of ruminants on fibrous crop residues (Edited by Singh, K. and Schiere, J. B.). Proceedings of an international workshop held at the national dairy research institute, Karnal (Haryana-India). pp. 141-146.

Turki, I.Y., Mawhip, A.M. Muna, E.K., Miriam, S.A., Omer, M.E. and Hammed, M.E. 2012. Effect of feeding systems on milk yield and composition of local and cross bred dairy cows. Int. J. Sci. and Tech., 2(1):5-9.

Walli, T.K., Sampath, K.T., Rai, S.N. and Tamminga, S. 1993. Relevance of the RDP/UDP system doe feeding of ruminants in the tropics with emphasis on straw based diet. In: Feeding ruminants on fibrous crop residues (Editors, Kiran Singh and J. B. Schiere). Indian Council of Agricultural Research, Krishi Bhavan, New Delhi, India. Pp.157-170.

WHO (World Health Organization). 2002. World Health Report. Reducing Risks, Promoting Healthy Life. Geneva.

Wildman, E.E., Jones, G.M., Wagner, P.E., Boman, R.L., Trout, H.F. and Lesch, T.N. 1982. A dairy cow body condition scoring system and its relationship to selected production characteristics. J. Dairy Sci., 65:495-501.

Yoon, J.T., Lee, J.H., Kim, C.K., Chung, Y.C. and Kim, C.H. 2004. Effects of milk production, season, parity and lactation period on variations of milk urea nitrogen concentration and milk components of Holstein dairy cows. Asian-Aust. J. Anim. Sci., 17(4):479-484. 